\title{
TEACHERS' ATTITUDES TOWARD CONSTRUCTIVIST TEACHING OF SOCIAL STUDIES IN PRIMARY SCHOOLS (WITH THE EMPHASIS ON LEARNING FORMS)
}

\author{
Polona Jančičč ${ }^{1}$ Vlasta Hus ${ }^{2}$ \\ ${ }^{1}$ Faculty of Education, University of Maribor, Koroškacesta 160, 2000 Maribor, Slovenia \\ ${ }^{2}$ Faculty of Education, University of Maribor, Koroškacesta 160, 2000 Maribor, Slovenia
}

\begin{abstract}
Social studies is a subject that students in Slovenia encounter in grades 4 and 5 of elementary school. The empirical study was conducted among lower primary school teachers teaching social studies in grades 4 or 5 in the academic year 2015/2016. The research explores the use of and attitudes towards constructivist pedagogic forms and methods within this context. The constructivist approach emphasizes a student's active role in the education process, as well as their capability to develop their own knowledge by themselves, based on experience and previous knowledge. The results showed that teachers in class frequently carry out frontal teaching, which is followed by group teaching. However, they rarely carry out the individual form of learning. Teachers believe that the level of discipline in frontal classes is higher than in a classroom where students are more active. Teachers are also aware that students learn the most in independent work and not from receiving frontal teaching.
\end{abstract}

Keywords: Constructivism, learning forms, primary school, society, teachers.

\section{INTRODUCTION}

Social studies is a class that students encounter in grades 4 and 5 of primary school. A total of 175 lessons are dedicated to it, 70 in the $4^{\text {th }}$ grade and 105 in the $5^{\text {th }}$ grade. The emphasis of the class is on learning about the relationship between an individual, society and the natural environment. It includes goals from, inter alia, the fields of geography, sociology, history, ethnology, psychology, economics, politics, ethics, aesthetics, and ecology[1]. Teaching social studies can represent a great challenge to teachers, especially when helping primary school students construct meaningful concepts [2].

In the field of education, constructivism denotes theories of knowledge and learning theories derived from them, which are based on the postulation that knowledge is a human construct, whether it be the result of individual, narrower social or wider social activities [3]. Classes based on constructivist postulations emphasize learners' active role in educational processes and their ability to, with a teacher's guidance build new knowledge based on experience and background knowledge [2, 4].

In the teaching of primary school students, it should be noted that the nature of cognitive interaction between the objective and the subjective is considerably more difficult than in adults. This is due to reduced prior knowledge and experience. Their interests and desires are still unformed and at the same time strongly subjectively oriented. In school, learning by discovering and assimilating new knowledge, should take place in the close interaction between the objective and subjective cognitive factors. It is advisable to take into account and integrate personal experience into learning, as this is a basic condition for students to be more internally motivated and creatively active to their best potential [5].

In the subject social studies, students learn about real life and derive knowledge from their lives in community [6]. Therefore, it is important to understand that students, when acquiring new knowledge, recall previous experience and reconstruct it according to a new study material. The accuracy of pupils' newly constructed knowledge is confirmed or refuted by subsequent similar cases or when ideas are confirmed by the others involved in the education process [4]. Given that each student has their own individual life experience, we can expect that there will be a unique concept of new knowledge formed in each student. Students associate new knowledge with previous experience. Therefore, classes in social studies cannot be conducted as a "closed box", and a teacher in a classroom has to take into account the connection between teaching material and the knowledge that students daily acquire unconsciously [6]. It is important that a teacher knows how to use individualisation to come closer to an individual learner. All students do not necessarily have the same mental capacity, so teaching should take into account their stage of development, since only then will all students have equal opportunities for work and activity. As children grow and develop, the concept of how to acquire and organize information in their minds becomes more complex $[2,4,7]$.

Teaching according to the principles of constructivism is conducted in such a way that learning has its purpose and that purpose should be known to pupils. Therefore, in a 
constructivist teaching scenario it is necessary to induce a sense of need for knowledge in students, and to explain to them why and when this knowledge can be used [8]. In the classroom, it is necessary to create authentic tasks, where the task and the environment should be harmonized and adapted to the developmental stage of the students. Students should be offered strategies by means of which they can reach a solution to the problem, and a teacher should encourage students to test ideas via alternative methods and contexts. Finally, it is necessary to equip learners with the process of reflection on the content of learning, since they have to acquire reflexive skills independently of the teacher $[2,9,10]$.

In the educational process that follows, the constructivist approach can be used to evaluate and select appropriate teaching practices. Since classes based on constructivist postulations emphasize the learner's active role in educational processes, it is important to choose such teaching forms to enable students' active role. Teaching forms are organizational forms of educational process and arrange relationships between positions and roles of teachers and students. Teachers can choose from an array of teaching forms: frontal, group and individual form [11].

In the traditional concept of teaching, the latter was often illustrated as one-way didactic communication: (learning material) - a teacher - learning material - pupils. In today's education, the relationship between operators and other constitutive components of educational process are changing; nevertheless, traditional teaching still prevails in many places. Teachers should, in accordance with the constructivist conception of learning, by their positive attitude towards pupils and didactic communication as well as interaction, give rise to pupils' activity and encourage it. Constructivist theories do not provide requirements for the removal of teaching, but for changing it. Students must be provided with adequate and quality didactic conditions, including modern didactic teaching, to be able to construct knowledge through their own activities [12].

It should also be noted that the constructivist approach is designed in such a way that, by the rational use of its principles, elements and provided forms of work, there should be no conflict situations in the classroom. A teacher has to create the right conditions for learning processes and an encouraging social atmosphere, which can be done by a properly established and maintained system which allows undisturbed pedagogical work. Good teaching that motivates students and involves them in work rarely leads to problems in classroom, compared to poor teaching. Effective teaching is actually a preventative disciplinary measure that keeps students so involved and interested that they are not inclined to cause problems $[13,14,15]$.

Wong and Wong [16] insist that students must not be allowed to throw lessons into chaos. In order to prevent that, a smoothly functioning learning environment must be established and maintained, task oriented and predictable[16, 17].
As stated above, teaching according to the principles of constructivism is conducted in such a way that learning is as effective as can be. If many, though certainly not all, discipline problems can be prevented through effective and interesting teaching, then a teacher "must be foolish not to provide such teaching” $[15, \mathrm{p} .10]$.

\section{RESEARCH METHODOLOGY}

The purpose of the study was to examine representations of teaching methods in social studies based on constructivism. A complete research, containing other aspects of the constructivist approach to teaching the subject is available in Jančič master's thesis[18]. This paper focuses on the part of the research which surveys the views of teachers on the constructivist approach to teaching social studies, in relation to the following questions:

- What is the popularity of teaching social studies with teachers?

- What is the frequency of use of different learning forms in social studies?

- What is the opinion of teachers about the level of classroom discipline when using learning forms in which students are active?

- What is the level of teachers' agreement with the statement "Students learn best when they work on their own."?

- What is the level of teachers' agreement with the statement "Students learn more and better if I carry out a frontal lecture."?

- What is the level of teachers' agreement with the statement "I prefer to teach frontally, because thus I have a better overview over the course of the lesson."?

- What is the level of teachers' agreement with the statement "Dialogue or constructivist-based talk is better than a short and clear explanation of a teacher."?

During the analysis, checks were made for the existence of statistically relevant differences between participating teachers with regard to their working age, professional title, the grade they are teaching, the teaching environment and the teachers' attitudes towards teaching social studies.

The study was based on a descriptive and casual nonexperimental method of empirical research and was carried out individually and anonymously. We included 181 elementary school teachers teaching social studies in grades 4 or 5 in the academic year 2015/2016. The research sample evenly covered teachers from all Slovenia's regions.

The sample consisted of $49.2 \% 4^{\text {th }}$ grade teachers and $50.8 \%$ $5^{\text {th }}$ grade teachers. According to their professional titles, the sample consisted of $7.7 \%$ of teachers without a title, $28.2 \%$ 
of mentors, $58.0 \%$ of advisors and $6.1 \%$ of counsellors. In terms of seniority, the sample comprised $6.1 \%$ of teachers who have been teaching for up to 5 years, $11.0 \%$ from 6 to 10 years, $11.6 \%$ from 11 to 15 years, $12.7 \%$ from 16 to 20 years and above, and $58.6 \%$ of teachers who have taught for more than 20 years. In terms of the environment in which the primary school is located, $48.1 \%$ of teachers participating in the research teach at the elementary school which is located in a town, and $51.9 \%$ teach in rural areas.

A questionnaire with verified metric characteristics (validity, reliability, objectivity) was used for collecting data. Validity was provided by assigning the questionnaire to review, performing a pilot test, and then having it upgraded. Reliability was controlled by ensuring the questionnaire included detailed instructions and unambiguous specific questions. Reliability was monitored also when processing data by comparing the answers to content-related questions. Objectivity was controlled through the use of closed-ended questions, whereby one cannot change information by subjective assessment. The objectivity of instrument is based on individual responses without the presence of an assessor.

The data obtained from the questionnaire were analyzed using the SPSS statistics program. For data processing, we used basic descriptive statistics, frequency distribution, a non-parametrical Chi-Square test for independence, a Mann-Whitney test to determine the differences between the two groups of teachers (those in the $4^{\text {th }}$ grade and those in the $5^{\text {th }}$, as well as between the teachers working in a town and those working in a rural area) and a Kruskal-Wallis test to determine the differences between groups of teachers regarding their professional title and seniority.

\section{RESULTS AND DISCUSSION}

\subsection{The Popularity of Teaching the Subject Social}

\section{Studies}

First, teachers were asked to what extent they like to teach the subject social studies. $53.6 \%$ of the teachers like to teach the subject very much. The remaining $46.4 \%$ of the teachers like to teach the subject. None of the respondents answered that they do not like to teach the subject. The results gave an overview of the popularity of teaching the subject social studies. These data were also obtained so that in the process of analyzing the questions the results could be used to detect statistically significant differences among teachers according to the popularity of teaching the subject social studies.

\subsection{The Frequency of use of Different Teaching}

\section{Forms in Social Studies}

The purpose was to know what type of instruction teachers use in social studies and how often. The teachers had to grade individual forms of instruction (frontal teaching, group teaching and individual learning) with four levels of frequency: frequently (level 1), occasionally (level 2), rarely (level 3) and never (level 4). Results were examined to detect the possibility of the existence of statistically significant differences depending on seniority, professional title and a grade of teaching using $\chi^{2}$-test.

Table 1: Teaching forms

\begin{tabular}{|c|c|c|c|c|c|c|}
\hline \multirow[b]{2}{*}{$\begin{array}{l}\text { Teachin } \\
\text { g forms }\end{array}$} & \multicolumn{6}{|c|}{ Frequency of use of teaching forms } \\
\hline & $\begin{array}{l}\text { Frequen } \\
\text { tly } \\
\text { f } \\
\text { f } \% \\
\end{array}$ & $\begin{array}{l}\text { Occasiona } \\
\text { lly } \\
\mathrm{f} \\
\mathrm{f} \% \\
\end{array}$ & $\begin{array}{l}\text { Rare } \\
\text { ly } \\
\text { f } \\
\text { f \% } \\
\end{array}$ & $\begin{array}{l}\text { Neve } \\
\mathrm{r} \\
\mathrm{f} \\
\mathrm{f} \% \\
\end{array}$ & \begin{tabular}{|l|} 
Tota \\
1 \\
$\mathrm{f}$ \\
$\mathrm{f} \%$ \\
\end{tabular} & $\overline{\mathrm{x}}$ \\
\hline $\begin{array}{l}\text { Frontal } \\
\text { teaching }\end{array}$ & $\begin{array}{l}93 \\
51 \% \\
\end{array}$ & $\begin{array}{l}67 \\
37 \% \\
\end{array}$ & $\begin{array}{l}20 \\
11 \% \\
\end{array}$ & $\begin{array}{l}1 \\
1 \% \\
\end{array}$ & $\begin{array}{l}181 \\
100 \\
\% \\
\end{array}$ & 1.6 \\
\hline $\begin{array}{l}\text { Group } \\
\text { teaching }\end{array}$ & $\begin{array}{l}45 \\
25 \% \\
\end{array}$ & $\begin{array}{l}118 \\
65 \% \\
\end{array}$ & $\begin{array}{l}17 \\
9 \% \\
\end{array}$ & $\begin{array}{l}1 \\
1 \%\end{array}$ & $\begin{array}{l}181 \\
100 \\
\% \\
\end{array}$ & 1.9 \\
\hline $\begin{array}{l}\text { Individu } \\
\text { al } \\
\text { learning }\end{array}$ & $\begin{array}{l}38 \\
21 \% \\
\end{array}$ & $\begin{array}{l}94 \\
52 \%\end{array}$ & $\begin{array}{l}46 \\
25 \% \\
\end{array}$ & $\begin{array}{l}3 \\
2 \% \\
\end{array}$ & $\begin{array}{l}181 \\
100 \\
\% \\
\end{array}$ & 2.1 \\
\hline
\end{tabular}

From the table 1 it can be seen that social studies teachers frequently carry out frontal teaching $(\bar{x}=1.6)$. Just over half $(51.4 \%)$ of teachers carry out frontal teaching frequently. $37.0 \%$ of teachers carry it out occasionally and $11.0 \%$ of teachers rarely. Kramar [19] explains that in most classrooms and didactic tools are adapted to frontal teaching. This way of teaching is apparently also more economical, as one teacher works with a large number of pupils, there are less didactic resources required, and students can, within the prescribed time process, acquire a particular subject matter.

From the table it can also be seen that frontal teaching is followed by group teaching $(\bar{x}=1.9)$ Teachers ranked use of group teaching lower in frequency $(\bar{x}=1.9)$ than frontal instruction $(\bar{x}=1.6)$. Most teachers $(65.2 \%)$ used group teaching occasionally, a bit less $(24.9 \%)$ of them use it often, and 17 teachers $(9.4 \%)$ use it rarely. Only one teacher has indicated that they do not apply group teaching in social studies. In group work, the students are divided into small formal or informal groups. The whole process is guided by a teacher and their role is important. As Kramar[19] states, several studies have shown that group work provides better work discipline and efficiency. If a teacher wants to produce active learning, then group work and group teaching is a powerful tool that can provide success for all class members [20].

Students should learn how to become successful at collaborative learning, which is an unusually long and quite difficult process. However, it could be concluded that the positive achievements ultimately outweigh the length and complexity of collaborative group learning [21]. Many teachers are afraid of discipline problems resulting from active forms of learning and therefore do not implement them. However, working in a group does not mean that there is disorder in the classroom. Problems can be overcome with proper preparation of the task and of the students. The first rule to ensure discipline in collaborative learning is that each 
group must work at a volume level which does not disturb the other groups. The second rule relates to the transition from collaborative learning back to the frontal way of teaching. Before making the transition, it is necessary to arrange a non-verbal sign, following which the teacher will again take the floor. It is important that the rules of behaviour are clear. Establishing the rules at the beginning requires a huge effort from the teacher, but the effort pays off with smooth and disciplinarily unproblematic operation of groups and classes as a whole [20,22].

Most rarely teachers implement individual learning $(\bar{x}=2.1)$. The average value of frequency of individual learning is $\overline{\mathrm{X}}=2.1$, which means that teachers carry it out occasionally $(51.9 \%)$, rarely $(25.4 \%)$ and in the lowest percentage of frequency $(21.0 \%)$. Three teachers $(1.7 \%)$ indicated that they never apply an individual form of learning to social studies classes. In individual learning, each individual learner, in accordance with their personal abilities, undertakes the task. With younger students the individual work requires much more guidance and leadership from the teacher. Individual work must be completely adapted to an individual's characteristics and should be very well prepared.

\subsection{The Degree of Classroom Discipline when using}

\section{Learning Forms in which Students are Active}

Table 2: Number (f) and structural percentage (f\%) of estimation of higher level of discipline

\begin{tabular}{|l|l|l|}
\hline Answers & $\mathbf{f}$ & $\mathbf{f} \%$ \\
\hline YES & 34 & 18.8 \\
\hline NO & 82 & 45.3 \\
\hline Partially & 65 & 35.9 \\
\hline Together & $\mathbf{1 8 1}$ & $\mathbf{1 0 0 . 0}$ \\
\hline
\end{tabular}

From the table we can see that on this question the opinion of the teachers is considerably divided. $45.3 \%$ of teachers believe that during active participation of student classrooms discipline is not better than that at frontal teaching. 35.9\% of teachers believe that the discipline is partially better when using didactic strategies based on the constructivist approach, i.e. strategies in which a learner is more active. $18.8 \%$ of the teachers believe that in such a scenario discipline in the classroom is better. Teachers, therefore, mostly responded negatively to a constructivist approach, which is designed in such a way that, with thought-out use of its principles, elements, strategies and anticipated forms of work, it has a preventive effect on misbehaviour. Pšunder [14] states that well-designed lessons that motivate students and involve them in work lead less frequently to problems in classroom. It is important that pedagogic activities are adapted to pupils' age and developmental stage of learning[23, 24].

Nevertheless, the repeatedly emphasised active role of a learner must not be forgotten. Wong and Wong [16], using the principles of effective classroom discipline, explained that a student who is bored during lessons, develops behavioral problems. Excited students have neither the time nor the inclination to misbehave [15]. If we connect these assumptions to constructivist approach, we can conclude that such a state of mind in pupils cannot arise in this case. The processes of teaching have to be adapted to each individual. Consequently, it is impossible that a learner should be unsuccessful, because the tasks are suited to their skills. This does not mean that the tasks are easier and that students do not have problems with doing them, but that they learn through the process itself how to overcome these problems. As discussed above, constructivism encourages one's own construction of knowledge, a process which includes pupils' false beliefs, which, with a teacher's leadership, they later eliminate. Students who feel individually able, and valued as an important part of the classroom community, will not think about challenging the established discipline in the classroom [24].

A statistically significant difference can be seen in relation to the popularity of teaching the subject $\left(\chi^{2}=9.936, \mathrm{~g}=2\right.$, $\mathrm{p}=0.007)$. Teachers who like to teach social studies very much, believe that discipline is better when using didactic strategies in which a student is more active than it is in frontal teaching.

\subsection{Using Some Elements of Constructivism in the}

Context of Learning Forms in Social Studies

\section{Classes}

The teachers were offered a set of statements that relate to the methodical procedures and forms of teaching in social studies classes. Two statements were assembled in such a way that they were consistent with constructivist approach to teaching $(1,4)$, and two are such that were in conflict with it $(2,3)$. Each statement was graded using a five-point scale. The value of a position on a statement was determined from the lowest level of agreement (strongly disagree=1) to the highest level of agreement (totally agree=5). The table shows the statements and their average ranges, which are presented and interpreted separately, depending on their content, below.

Table 3: Number (f), structural percentage (f\%) and the average rank $(\mathrm{R})$ of answers of agreeing to a particular statement

\begin{tabular}{|c|c|c|c|c|c|c|c|}
\hline \multirow[b]{2}{*}{ Statement } & \multicolumn{7}{|c|}{ Answers } \\
\hline & $\begin{array}{l}\text { Stron } \\
\text { gly } \\
\text { disag } \\
\text { ree } \\
\text { f } \\
\text { f \% }\end{array}$ & $\begin{array}{l}\text { Do } \\
\text { not } \\
\text { agr } \\
\text { ee } \\
\text { f } \\
\text { f } \%\end{array}$ & $\begin{array}{l}\text { Partia } \\
\text { lly } \\
\text { agree } \\
\text { f } \\
\text { f \% }\end{array}$ & $\begin{array}{l}\text { Agr } \\
\text { ee } \\
\text { f } \\
\text { f } \%\end{array}$ & $\begin{array}{l}\text { Tota } \\
\text { lly } \\
\text { agre } \\
\text { e } \\
\text { f } \\
\text { f } \%\end{array}$ & $\begin{array}{l}\text { Tot } \\
\text { al } \\
\text { f } \\
\text { f } \%\end{array}$ & $\overline{\mathrm{R}}$ \\
\hline $\begin{array}{l}1 . \\
\text { Students } \\
\text { learn best } \\
\text { when } \\
\text { they } \\
\text { work on } \\
\text { their } \\
\text { own. }\end{array}$ & $\begin{array}{l}4 \\
2.2 \%\end{array}$ & $\begin{array}{l}10 \\
5.5 \\
\%\end{array}$ & $\begin{array}{l}66 \\
36.5 \\
\%\end{array}$ & $\begin{array}{l}75 \\
41.4 \\
\%\end{array}$ & $\begin{array}{l}26 \\
14.4 \\
\%\end{array}$ & $\begin{array}{l}181 \\
100 \\
\%\end{array}$ & $\begin{array}{l}3 . \\
60\end{array}$ \\
\hline
\end{tabular}




\begin{tabular}{|c|c|c|c|c|c|c|c|}
\hline $\begin{array}{l}2 . \\
\text { Students } \\
\text { learn } \\
\text { more and } \\
\text { better if I } \\
\text { carry out } \\
\text { a frontal } \\
\text { lecture. }\end{array}$ & $\begin{array}{l}22 \\
12.2 \\
\%\end{array}$ & $\begin{array}{l}61 \\
33 . \\
\%\end{array}$ & $\begin{array}{l}74 \\
40.9 \\
\%\end{array}$ & $\begin{array}{l}22 \\
12.2 \\
\%\end{array}$ & $\begin{array}{l}2 \\
1.1 \\
\%\end{array}$ & $\begin{array}{l}180 \\
100 \\
\%\end{array}$ & $\begin{array}{l}2 . \\
56\end{array}$ \\
\hline $\begin{array}{l}\text { 3. I prefer } \\
\text { to teach } \\
\text { frontally, } \\
\text { because } \\
\text { thus I } \\
\text { have a } \\
\text { better } \\
\text { overview } \\
\text { over the } \\
\text { course of } \\
\text { the } \\
\text { lesson. }\end{array}$ & $\begin{array}{l}32 \\
17.7 \\
\%\end{array}$ & $\begin{array}{l}60 \\
33 . \\
\%\end{array}$ & $\begin{array}{l}68 \\
37.6 \\
\%\end{array}$ & $\begin{array}{l}16 \\
8.8 \\
\%\end{array}$ & $\begin{array}{l}5 \\
2.8 \\
\%\end{array}$ & $\begin{array}{l}181 \\
100 \\
\%\end{array}$ & $\begin{array}{l}2 . \\
46\end{array}$ \\
\hline $\begin{array}{l}4 . \\
\text { Dialogue } \\
\text { or } \\
\text { constructi } \\
\text { vist- } \\
\text { based } \\
\text { talk is } \\
\text { better } \\
\text { than a } \\
\text { short and } \\
\text { clear } \\
\text { explanati } \\
\text { on of a } \\
\text { teacher. }\end{array}$ & $\begin{array}{l}1 \\
0.6 \%\end{array}$ & $\begin{array}{l}8 \\
4.4 \\
\%\end{array}$ & $\begin{array}{l}47 \\
26.0 \\
\%\end{array}$ & $\begin{array}{l}97 \\
53.6 \\
\%\end{array}$ & $\begin{array}{l}28 \\
15.5 \\
\%\end{array}$ & $\begin{array}{l}181 \\
100 \\
\%\end{array}$ & $\begin{array}{l}3 . \\
79\end{array}$ \\
\hline
\end{tabular}

What is the level of teachers' agreement with the statement "Students learn best when they work on their own."?

Teachers mostly agree or partially agree with this statement $(\overline{\mathrm{R}}=3.60)$. The structural percentage of those who totally agree with the statement $(14.4 \%)$ is equal to the sum of those who strongly disagree $(2.2 \%)$ and those who do not agree with the statement $(5.5 \%)$. We can be very satisfied with the result, since in accordance with the development of the teacher's thinking there is also a need for newer, more active teaching methods, which fosters the development of didactic movements. The constructivist approach emphasizes that learners should build their own knowledge, since such knowledge lasts longer and is more stable [2, 4]. According to the study results, teachers agree that students learn most when they work alone.

What is the level of teachers' agreement with the statement "Students learn more and better if I carry out a frontal lecture."?

According to the results, teachers mostly disagree with the above statement $(\overline{\mathrm{R}}=2.56)$. The majority of teachers $(40.9 \%)$ marked that they partially agree with the statement. $33.7 \%$ of teachers do not agree with this statement; $12.2 \%$ of teachers, however, strongly disagree with this statement. If we compare the position of teachers upon the previous statement, which says that students learn best when they work independently, the result of this question is to be expected. Frontal lessons significantly reduce pupils' activity in the subject social studies.

What is the level of teachers' agreement with the statement "I prefer to teach frontally, because thus I have a better overview over the course of the lesson."?

This statement was put in the category "partially agree" $(\overline{\mathrm{R}}=2.46) .37 .6 \%$ of teachers partially agree that they prefer to teach frontally because thus they have a better overview over the course of the lesson. $33.1 \%$ of the surveyed teachers disagree and $17.7 \%$ of teachers strongly disagree with this statement. We can observe teachers' general opinion that they can have an appropriate overview of the course of the lesson in other forms and methods of working as well.

What is the level of teachers' agreement with the statement "Dialogue or constructivist-based talk is better than a short and clear explanation of a teacher."?

The interviewed teachers agree that a dialogue or constructivist-based talk is better than a short and clear explanation of a teacher $(r=3.79) .53 .6 \%$ of teachers agree with the statement, $15.5 \%$ of teachers totally agree with the statement and $26.0 \%$ of teachers partially agree with the statement. From the constructivist perspective, a dialogue is one of the main methods that are recommended to be used in classes. A good dialogue should help a student develop and construct knowledge, or even dissolve their existing conceptions and imperfect and incorrect knowledge[10]. However, good facilitation of a constructivist-based dialogue is quite difficult, as it requires from the teacher a series of practical skills and more substantive knowledge than a traditional dialogue. As a consequence, teachers do make use of such a discussion as much as they could. The traditional process of dialogue, which can be defined as question - answer - feedback, comprise up to $90 \%$ of teaching time. However, despite all the advantages, we cannot expect a constructivist conversation to completely replace a traditional conversation. MarentičPožarnik[10] further points out that a traditional course of conversation also has its irreplaceable role, since with it students gain a sense of certainty that knowledge is already here and it is not necessary to build everything anew.

In relation to the class taught, a statistically significant difference can be identified on the statement that conversation or constructivist-based talk is better than a short and clear explanation from a teacher (IZI=-2.006, $\mathrm{p}=0.045$ ). Teachers of grade 4 statistically agree more with it than teachers of grade 5 . It would be interesting to do a survey among teachers in the future which would determine the reasons for such thinking. 


\section{CONCLUSION}

This empirical study was designed to examine the representation of the constructivist approach in the teaching of the subject social studies. From the results we can see that teachers frequently carry out frontal lessons in this subject. With the same average value, frontal lessons are followed by group learning. The most rarely carried out form is individual learning. The comparison of the frequency of use of forms of teaching to seniority, professional title and the grade taught revealed no statistically significant differences.

In the most commonly used frontal teaching, a teacher's role is at the forefront and often dominates, which has its advantages and disadvantages. The process of teaching is carried out in such a way that students are at a disadvantage and their activity is limited to listening and watching. From the perspective of constructivism this is bad, because the acquisition of knowledge is carried out as giving-receiving and not as pupils' own structuring.

However, such an organization of class may also be relevant and valuable if we prevent or reduce disadvantages through a combination of different forms of teaching [19]. Teachers who most often use frontal teaching should be encouraged to combine or interleave it with some form of learning in which students are more active. A teacher has to, in the process of teaching, maintain the authority and role of the representative of "true" knowledge. In summary, it could be said that the teacher's role is not becoming weaker, yet it is still extremely difficult, responsible and multi-layered [10].

Teachers claim that students learn most and best in independent work and not by the implementation of frontal teaching. They add that frontal teaching does not provide a better overview of the course of a lesson. At the same time, they believe that frontal teaching provides more discipline than where a constructivist approach is used (i.e. strategies, methods and forms of teaching in which a student is more active). Teachers, therefore, in regard to the disciplinary element of the educational process, in most cases answered contrary to the idea of using a constructivist approach, though it is designed in such a way that by a thought-out use of its principles, elements and strategies and anticipated forms of work, it has a preventive effect on misbehaviour. Pšunder[14], Wiseman and Hunt [24] and some other authors referred to above, explain that well-designed lessons that motivate students and involve them in work rarely lead to problems in the classroom.

The results obtained provide an overview of the use of forms of work in the classroom, and of teachers' opinions on the importance of certain elements of the constructivist approach for lessons in social studies. These insights may help in the planning of education and training for teachers to upgrade their teaching.

\section{REFERENCES}

[1]. Budnar, M., Kerin, M., Umek, M., Raztresen, M., \& Mirt, G. (2011). Učninačrt. Program osnovnašola. Družba.[Primary school curriculum for social studies].. Ljubljana: Ministrstvozašolstvo in šport, Zavod RS zašolstvo.

[2]. Maxim, G. W. (2010). Dynamic social studies for constructivist classrooms. Boston, MA: Pearson Education, Inc.

[3]. Plut-Pregelj, L. (2004): Konstruktivistične teorije znanja in šolska reforma: učitelj v vlogi učenca. V B. Marentič Požarnik (Ur.), Konstruktivizem v šoli in izobraževanje učiteljev[Constructivism in School and Teacher Education]. (pp. 17-40). Ljubljana: Center za pedagoško izobraževanje filozofske fakultete.

[4]. Martin, D. J. (2001). Constructing early childhood science. Albany, NY: Delmar Thomson Learning.

[5]. Strmčnik, F. (2003). Didaktičneparadigme, koncepti in strategije. [Didactics paradigms, concepts and strategies].. Sodobnapedagogika. [Journal of Contemporary Educational Studies]., 54(1), 80-93.

[6]. Mishra, R. K. (2015). Teaching-Learning in a constructivist social science classroom. Journal of Educational Sciences \& Psychology, 5(2), 15-22.

[7]. Naude, L., Bergh, T., \& Kruger, I. (2014). 'Learning to like learning': An appreciative inquiry into emotions in education. Social Psychology of Education, 17(2), 211-228.

[8]. Fitzgerald, A., \& Smith, K. (2016). Science that matters: Exploring science learning and teaching in primary schools. Australian Journal of Teacher Education, 41(4), 64-78.

[9]. Gojkov, G. (2004). Konstruktivizemkotepistemološkaosnovapostmodernedidakt ike. V B. MarentičPožarnik (Ur.), Konstruktivizem v šoli in izobraževanjeučiteljev. [Constructivism in School and Teacher Education]. (pp. 123-134). Ljubljana: Centerzapedagoškoizobraževanjefilozofskefakultete.

[10]. MarentičPožarnik, B. (2008). Konstruktivizemnapotiodteorijespoznavanja do vplivanjanapedagoškorazmišljanje, raziskovanje in učnoprakso. [Constructivism on the way from epistemological theory to educational thinking, research and teaching practice.]. V Sodobnapedagogika [Journal of Contemporary Educational Studies]., 59(125), 28-51.

[11]. Blažič, M., IvanušGrmek, M., Kramar, M., \&Strmčnik, F. (2003). Didaktika.[Didactics].. Novo mesto: Visokošolskosredišče, Inštitutzaraziskovalno in razvojnodelo.

[12]. Kramar, M. (2004). Konstruktivizem in učiteljeva vloga v izobraževalnem procesu. V B. Marentič Požarnik (Ur.), Konstruktivizem $v$ šoli in izobraževanje učiteljev [Constructivism in School and Teacher Education]. (pp. 113-122). Ljubljana: Center za pedagoško izobraževanje filozofske fakultete.

[13]. Glasser, W. (1990). The quality school: Managing students without coercion. New York, NY: Harper and Row. [14]. Pšunder, M. (2004). Disciplina v sodobni šoli. Ljubljana: Zavod Republike Slovenije za šolstvo.

[15]. Tauber, R., S. (2007). Classroom management: Sound theory and effective practice $\left(4^{\text {th }} \mathrm{Ed}\right.$.). London: Praeger. 
[16]. Wong, H., \& Wong, R. (2004). The first days at school: How to be an effective teacher. Mountain View, CA: Harry K. Wong.

[17]. Charles, C. M. (2008). Today's best classroom management strategies: Paths to positive discipline. Boston, MA: Pearson/Allyn Bacon.

[18]. Jančič (2016). Zastopanostkonstruktivističnegapristopapripoukudružbe.

[The representation of the constructivist approach in social studies].. Magistrskodelo. Univerza v Mariboru, Pedagoškafakulteta, Maribor.

[19]. Kramar, M. (2009). Pouk. Nova Gorica: Educa, Melior.

[20]. Cohen, E. G., \&Lotan, R. A. (2014). Designing groupwork: Strategies for the heterogeneous classroom. New York,NY: Teachers College Press.

[21]. Pekljaj, C. (2004). Tekmovanje, sodelovanje in individualno učenje ter razvoj različnih kompetenc.V Vzgoja in izobraževanje [Education and training]., 35(4), p. 4-12. Ljubljana: Zavod RS za šolstvo.

[22]. Pekljaj, C. (2001). Sodelovalno učenje ali kdaj več glav več ve. Ljubljana: DZS.

[23]. Jones V. F., \& Jones S. J. (1998). Comprehensive classroom management: Creating communities of support and solving problems. Boston, MA: Allyn and Bacon.

[24]. Wiseman, D. G., \& Hunt, G. H. (2008). Best practice in motivation and management in the classroom (2nd Ed.). Springfield, IL: Thomas Books.

\section{BIOGRAPHIES}

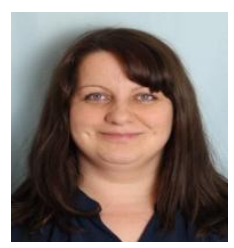

Asist. mag. Polona Jančič works at the Department of Elementary Education at University of Maribor. Her research interest includes constructivist approach towards teaching and learning in primary education.

e-mail: polona.jancic1@um.si

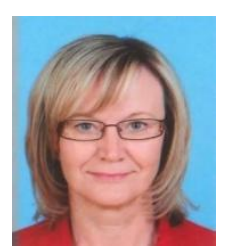

Prof. Dr. Vlasta Hus works at the Department of Elementary Education at University of Maribor. Her main research interests are curricular changes of Environmental and Social Studies Subjects. e-mail: vlasta.hus@um.si 